\title{
Impact of Soil \\ Drainage on \\ Growth, \\ Productivity, \\ Cane Dieback, \\ and Fruit \\ Composition of \\ 'Chambourcin' \\ and 'Pinot Gris' \\ Grapevines
}

\author{
Maurus V. Brown, ${ }^{1}$ \\ David C. Ferree, ${ }^{2}$ \\ David M. Scurlock, ${ }^{3}$ and \\ Gene Sigel $^{4}$
}

Additional index words. Vitis, grape, bulk density, root growth, soil aeration, French hybrid, V. vinifera, tiling

Summary. In the Spring and Summer 1997, severe die back of 'Pinot Gris' and 'Chambourcin' grape (Vitis vinifera) vines was observed by aerial surveillance in a commercial vineyard adjacent to Lake Erie. Vines grown over the tile lines grew well during 1997-99 following the excessively wet year of 1996. This was not the case for vines that were located between

\footnotetext{
Department of Horticulture and Crop Science, The Ohio State University, Ohio Agricultural Research and Development Center, Wooster, OH 44691

Salaries and research support provided by state and federal funds appropriated to the Ohio Agricultural Research and Development Center, The Ohio State University. Manuscript number. HCS 99-41. Partial funding for this project came from the Ohio Grape Industries Program and the Viticulture ConsortiumEast program through a subcontract with Cornell University, New York State Agricultural Experiment Station. The cost of publishing this paper was defrayed in part by the payment of page charges. Under postal regulations, this paper therefore must be hereby marked advertisement solely to indicate this fact.

${ }^{1}$ Former extension associate viticulturist. Currently extension agent, Ohio State University Extension, Richland County Extension Office, Mansfield, $\mathrm{OH}$ 44906.

${ }^{2}$ Professor.

${ }^{3}$ Research associate.

${ }^{4}$ Vineyard manager, Chalet Debonné Vineyards, Madison, $\mathrm{OH}$.
} 
tile lines. It was postulated that by digging and refilling the trench to insert the tile that either soil compaction or soil $\mathrm{pH}$ had been altered and could be responsible for the vine performance. Measurements indicated that these factors were not altered enough to explain the growth differences between vines growing over tile lines and those vines growing between tile lines. It appears that soil oxygen was improved by tiling and likely made the difference in cane dieback during the excessively wet year of 1996. By 1999, vines over tile and between tile had similar yields, and the pattern was no longer visible from the air. This study showed that heavy clay soils with naturally poor internal drainage caused cane dieback and poor growth of vines, especially in very wet years. Thus, it appears prudent on soils of this type, tile drainage is beneficial and spacing of lateral tile lines needs to be closer than $40 \mathrm{ft}(12 \mathrm{~m})$ in plateau silt loam soils to adequately protect vines from wet years.
$\mathrm{I}$ n 1996, Ohio experienced one of the wettest years on record and rainfall was above the long term average every month of the year and was particularly excessive and consistently high in the period June through September (Fig. 1).

Soil in Chalet Debonne Vineyard, Madison, Ohio, near Lake Erie is of the Platea silt loam series and formed on a Wisconsin glacial till plane with sediments of clayey shale and siltstone (USDA Soil Conservation Service, 1973 ). Platea silt loam contains $22 \%$ to $34 \%$ clay and fragipans can be found from 14.1 to 26.0 inches (36 to 66 $\mathrm{cm}$ ) below the soil surface (USDA Soil Conservation Service, 1973; Zucker and Brown, 1998). This soil series has poor internal drainage during periods of high precipitation and it has been classified in the drainage group E-4 (USDA Soil Conservation Service, 1973). Soils that are composed primarily of clay and silt are more prone to poor infiltration and percolation than soils with a high sand content.
Soil compaction can readily occur during wet periods in which soils are often at field capacity when growers use heavy spray equipment in the spring or remove fruit at harvest. As equipment repeatedly passes over the same area in vineyard there is a greater potential for soil bulk density to increase. Few grape growers implement some type of drainage program to encourage drainage and lower the water table to enhance trafficability of equipment in fields.

Vine vigor and productivity have been shown to improve by the use of field tile in Ontario, Canada (Fisher, 1997). An increase in plant vigor appeared to be related to improved soil drainage and possibly due to an increase of oxygen in the root zone. Stressed grapevines could result in low root volume which may limit carbohydrate reserves and hormone levels which could lead to increased winter injury and result in poor shoot emergence (McArtney and Ferree, 1999a, 1999b).

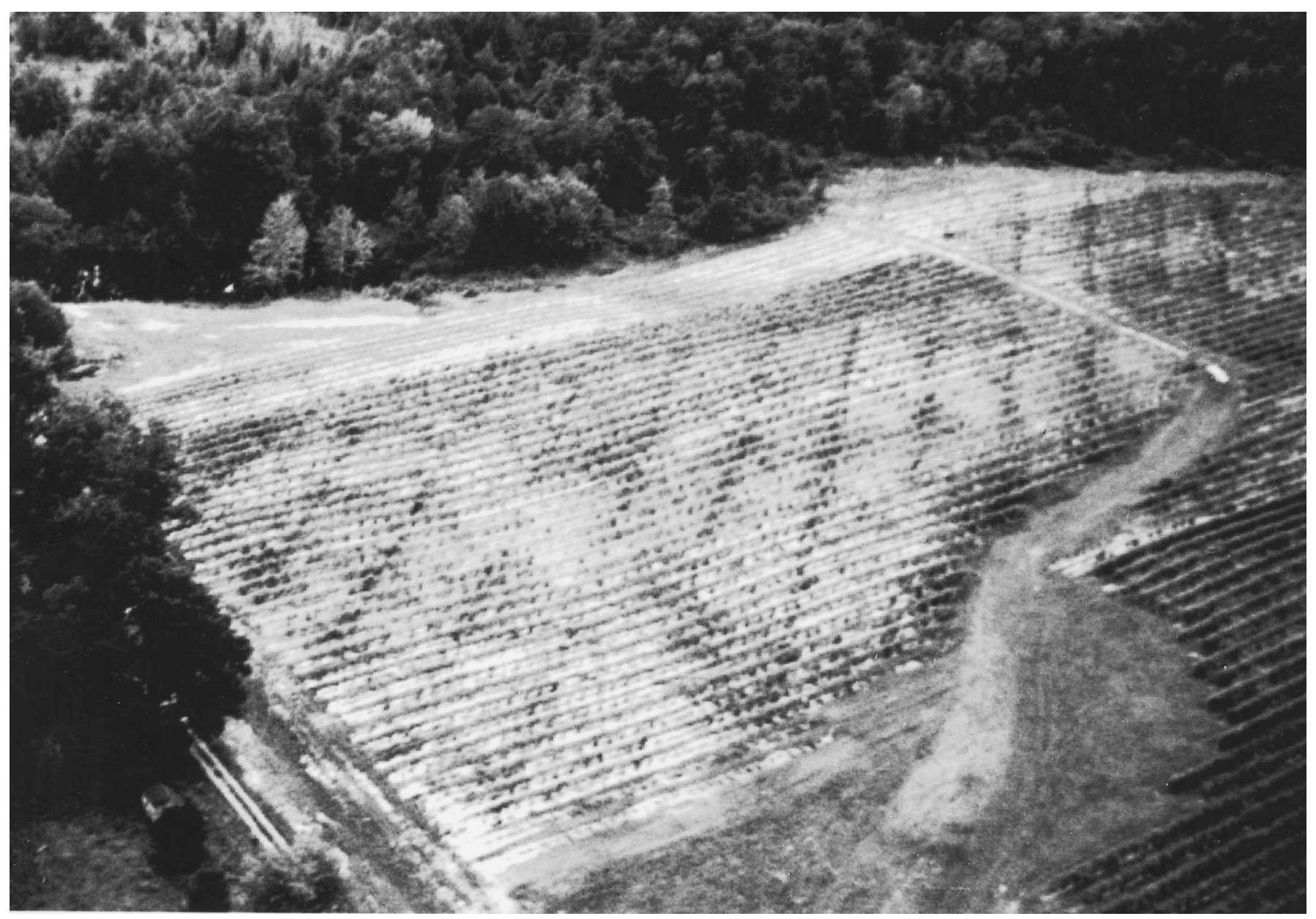

Fig. 1. Aerial view of the vineyards in 1997 showing the diagonal pattern due to vigorous vines over the tile lines with weak vines between the tile lines. 
Table. I Influence of tiling on yield, cluster size, berry weight, and fruit chemical analysis of 'Chambourcin' and 'Pinot Gris' at Chalet Debonné Vineyards, Madison, Ohio in 1998 and $1999\left(1.0 \mathrm{~g} \cdot \mathrm{L}^{-1}=1000 \mathrm{ppm}, 1.001 \mathrm{~b}=0.454 \mathrm{~kg}, 28.35 \mathrm{~g}=1.0 \mathrm{oz}\right)$.

\begin{tabular}{|c|c|c|c|c|c|c|c|c|}
\hline \multirow[b]{3}{*}{ Treatment } & \multicolumn{2}{|c|}{ Pruning $^{z}$} & \multirow{3}{*}{$\begin{array}{c}\text { Avg } \\
\text { cluster } \\
\text { wt } \\
(\mathbf{l b})\end{array}$} & \multirow[b]{3}{*}{$\begin{array}{c}\text { Yield } \\
\text { (lb/vine) }\end{array}$} & \multirow{3}{*}{$\begin{array}{c}\text { Berry } \\
\text { wt } \\
(\mathrm{g})\end{array}$} & \multirow{2}{*}{\multicolumn{3}{|c|}{$\begin{array}{c}\text { Fruit } \\
\text { composition }\end{array}$}} \\
\hline & \multirow{2}{*}{$\begin{array}{l}\text { Live } \\
\text { wt } \\
(\mathbf{l b})\end{array}$} & \multirow{2}{*}{$\begin{array}{c}\text { Dead } \\
\text { wt } \\
(\mathbf{l b})\end{array}$} & & & & & & \\
\hline & & & & & & $\begin{array}{l}\text { TSS } \\
(\%)\end{array}$ & $\mathbf{p H}$ & $\begin{array}{c}\mathbf{T A}^{\mathbf{x}} \\
\left(\mathrm{g} \cdot \mathbf{L}^{-1}\right)\end{array}$ \\
\hline & \multicolumn{8}{|c|}{ 'Chambourcin' } \\
\hline Nontile & 1.04 & 0.07 & 0.37 & $27.3 \mathrm{~b}$ & $1.90 \mathrm{~b}$ & 20.7 & 3.14 & 10.4 \\
\hline Tile & 1.62 & 0.10 & 0.42 & $37.2 \mathrm{a}$ & $2.10 \mathrm{a}$ & 20.7 & 3.14 & 10.4 \\
\hline 1998 & $0.94 b$ & $0.03 \mathrm{~b}$ & $0.34 \mathrm{~b}$ & $20.7 \mathrm{~b}$ & 2.03 & $22.0 \mathrm{a}$ & $3.17 \mathrm{a}$ & $11.1 \mathrm{a}$ \\
\hline \multirow[t]{2}{*}{1999} & $1.72 \mathrm{a}$ & $0.13 \mathrm{a}$ & $0.45 \mathrm{a}$ & $44.6 \mathrm{a}$ & 1.97 & $19.4 \mathrm{~b}$ & $3.10 \mathrm{~b}$ & $9.8 \mathrm{~b}$ \\
\hline & \multicolumn{8}{|c|}{ 'Pinot Gris' } \\
\hline Nontile & $0.53 \mathrm{~b}$ & $0.03 \mathrm{~b}$ & 0.20 & 19.9 & 1.45 & 17.8 & 3.33 & 06.0 \\
\hline Tile & $1.04 \mathrm{a}$ & $0.07 \mathrm{a}$ & 0.20 & 22.3 & 1.50 & 18.4 & 3.29 & 06.2 \\
\hline 1998 & $0.32 b$ & $0.03 \mathrm{~b}$ & $0.19 \mathrm{~b}$ & $15.6 \mathrm{~b}$ & $1.68 \mathrm{a}$ & 18.7 & $3.28 \mathrm{~b}$ & 06.2 \\
\hline 1999 & $1.25 \mathrm{a}$ & $0.07 \mathrm{a}$ & $0.22 \mathrm{a}$ & $26.6 \mathrm{a}$ & $1.27 \mathrm{~b}$ & 17.5 & $3.35 \mathrm{a}$ & 06.1 \\
\hline
\end{tabular}

${ }^{\mathrm{z}}$ Data followed by different letters are significantly different at LSD $\mathrm{P}<0.05$

yTSS $=$ total soluble solids.

${ }^{\mathrm{x}} \mathrm{TA}=$ titratable acidity, $\%$ tartaric acid.

In an attempt to determine what caused the distinct difference in vine growth, a study was established to evaluate the differences in the vines and soil immediately over the tile lines and vines and soil in the center between the lines. A separate study was conducted in the 'Pinot Gris' and 'Chambourcin' vineyards which were adjacent.

\section{Materials and methods}

Site. The vineyard site at Chalet Debonné Vineyards was tiled with diagonal laterals to the field edges (USDA Soil Conservation Service, 1973) in 1992 using 4 -inch $(10-\mathrm{cm})$ diameter tile spaced $40 \mathrm{ft}$ apart (Fig. 1).

Plant material. 'Chambourcin' / 'Couderc 3309' ('3309C') (planted in $1995)$ and 'Pinot Gris'/'3309C' (planted in 1994) grapevines from Chalet Debonné Vineyards were used in this study. Grapevines were selected according to their position to tile lines, and they were either over a tile or midway between two lateral tiles (Fig. 1). All grapevines were trained to a low cordon [30 inches $(76 \mathrm{~cm})$ from ground] and vertically shoot positioned. One-yearold canes were pruned to three to four nodes/spur.

Data collected. Data were recorded on plant performance including weight of cane prunings, yields, cluster and berry weights, and fruit composition in 1998 and 1999. Penetrometer (Investigator Soil Compaction Meter; Spectrom Technologies, Inc., Plainfield, Ill.) readings were recorded at 2 -inch $(5-\mathrm{cm})$ intervals to a depth of 16 inches $(40 \mathrm{~cm})$ in the row 12 inches $(30 \mathrm{~cm})$ from the vine, in the equipment track, parallel to the row and in the row center. Five oxygen probes were inserted at 6and 18 -inch depths ( 15 and $45 \mathrm{~cm}), 12$ inches from each vine (Oxygen Diffusion Ratemeter, model D; Jenson Instruments, Tacoma, Wash.) in the soil. Soil samples were collected 12 inches from each plant at 6, 12, and 18 inches deep to determine soil relative water content and $\mathrm{pH}$. Pentrometer, oxygen readings and soil samples were taken in April 1999 with the soil moisture at field capacity.

Experimental design and analysis. The treatments were made using a completely randomized design with seven replications per treatment in 'Chambourcin' and 'Pinot Gris' vineyards. Data from each vineyard were analyzed using SAS statistical package (SAS Institute, 1996) with mean separation by LSD.

\section{Results and discussion}

VINE GROWTH AND PRODUCTION. Pruning weight of live and dead wood from 'Chambourcin' grapevines grown over tile were not significantly greater than vines not located near a tile (Table 1 ). 'Pinot Gris' grapevines grown over tile had a significantly higher amount live and dead pruning wood than vines not tiled (Table 1). Live and dead pruning wood were higher for both cultivars in 1999 than in 1998.

Yield of 'Chambourcin' was also significantly greater on grapevines grown over tile compared to vines not located near tile. Cluster weight of 'Pinot Gris' was higher in 1999 than in 1998. Yield in 1999 was higher for both cultivars compared to 1998 and proximity to the tile line had no effect on yield in 1999. Tiling significantly increased the berry weight in 'Chambourcin', but had no significant influence on 'Pinot Gris' berry weight. In the study conducted by Fisher (1997) yields in tiled areas were greatly increased over nontiled areas. Vine growth and productivity increased to a greater extent in response to tiling in poorly drained fields than in well drained fields. This study supports the results found by Fisher (1997) that it is important to remove excess water from the soil profile to improve vine productivity.

The significant differences in 1999 and 1998 data could be attributed to the time required for the vines to recover from the 1996-97 wet conditions (Fig. 2) and subsequent winter damage. By 1999, most of the vines were reestablished on the trellis. Both 'Chambourcin' and 'Pinot Gris' were grown on '3309C' rootstock which has been determined to be a good rootstock for heavier clay soils and Ohio growing conditions (Ferree et al., 1996).

Fruit COMPOSITION. Juice made from 'Chambourcin' and 'Pinot Gris' did not differ in total soluble solids (TSS), $\mathrm{pH}$, and titratable acidity (TA) when comparing tiled versus non-tiled grapevines (Table 1). Soluble solids and TA of 'Chambourcin' fruit were higher in 1998 than in 1999, which was likely due to the lower crop in 1998. No significant differences were found in $\mathrm{pH}$ of 'Chambourcin', however $\mathrm{pH}$ of 'Pinot Gris' fruit was significantly greater in 1999 than 1998 (Table 1). In this study, fruit composition was more influenced by growing season and crop level than 


\section{Precipitation in Inches}
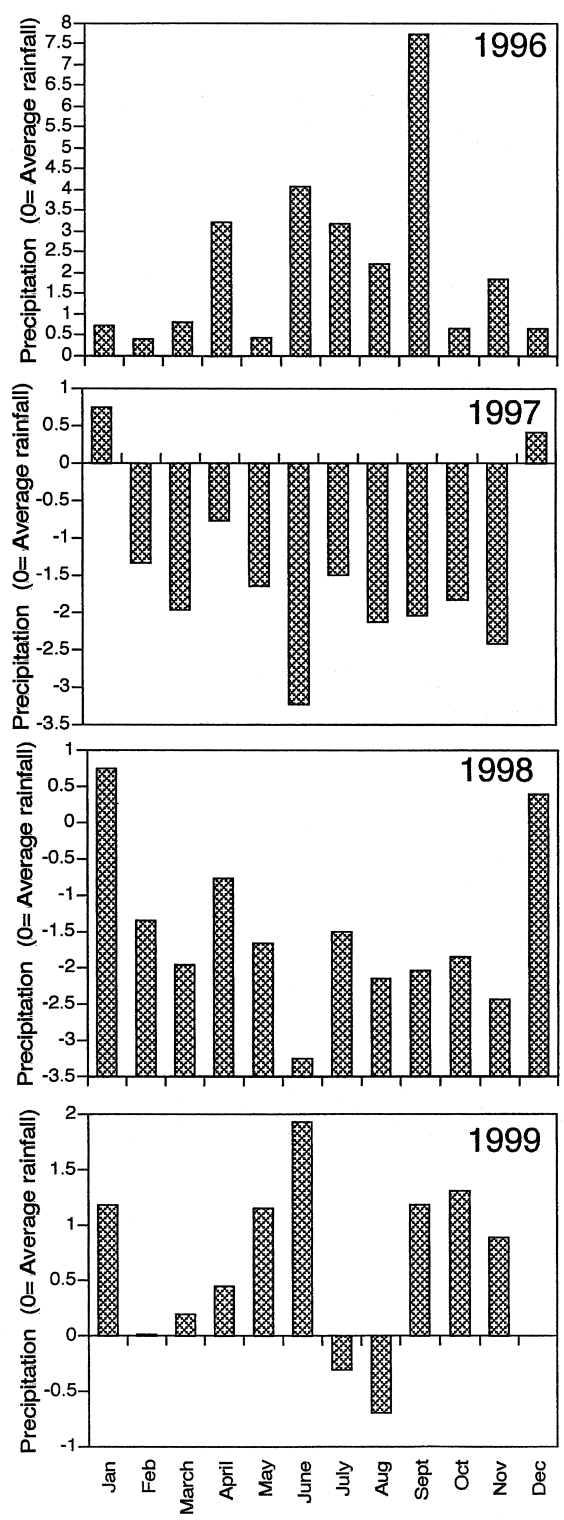

Fig. 2. Monthly precipitation from 1996 to 1999 compared to the long time average for northeastern $\mathrm{Ohio} ; 1.0 \mathrm{inch}$ $=2.54 \mathrm{~cm}$. by soil moisture. Environmental factors including sunlight, temperature, and rainfall probably had a greater impact on fruit quality than the soil moisture content.

SOIL PH AND RELATIVE WATER CONTENT. Soil in the 'Chambourcin' and 'Pinot Gris' vineyards showed a significant decreasing linear relationship in $\mathrm{pH}$ with depth of the soil profile (Table 2 ). There was no difference between the $\mathrm{pH}$ of the control soil sample and the sample taken over the tile lines in the 'Chambourcin' vineyard. In the 'Pinot Gris' vineyard, however, $\mathrm{pH}$ of the soil that had been mixed when the tile was installed was higher than the $\mathrm{pH}$ of the undisturbed soil between tile lines. The soil in the 'Pinot Gris' vineyard was less acidic overall than the 'Chambourcin' vineyard. There was no interaction between tilage and soil depth.

Relative water content (RWC) in the 'Chambourcin' vineyard decreased down through the soil profile. However, RWC in the 'Pinot Gris' vineyard was higher at 12 inches than at either 6 or 18 inches (Table 2). Since the Platea soil is known to have fragipans, these impervious layers may have reformed after the tile lines were established resulting in an increase in percent relative water content at 12 inches. There was no significant difference in soil relative water content between tiled versus nontiled soil in either vineyard, which indicated that there was no evident tiling affect on soil drainage or water holding capacity (Table 2). However, this likely was very different in 1996 with the very wet conditions and the tile would result in facilitating removal of excess water from the soil profile.

Soll compaction. Soil compaction as measured by penetrometer was significantly greater in the equipment track than in the soil around the plants in both vineyards, except at the 8-inch level in the 'Pinot Gris' vineyard where there was no significant difference (Table 3 ). Track and aisle compaction were significantly different at each soil level, except for the 2, 14, and 16-inch levels in the 'Chambourcin' vineyard, and the 14and 16-inch levels in the 'Pinot Gris' vineyard. These results would support the concept that repeated passes of equipment through the vineyards caused increased soil compaction in the track area. The compaction could severely reduce water percolation through the soil profile in the tracks. When considering the entire soil profile in the plant area, there does not appear to be a problem with compaction (Table 3 ). Tiled areas tended to dry much quicker than nontiled following heavy rains and this was also the case in the study conducted by Fisher (1997). Well drained soils will undoubtedly provide greater trafficability when producers are spraying in early spring and harvesting in the fall.

Soll oxygen. Soil over the tile lines had higher soil oxygen levels than soil in between tile laterals (Table 4). No significant difference was found between the oxygen levels in soil of the 'Chambourcin' and 'Pinot Gris' vineyards. Oxygen levels were higher at the 6-inch level than at 18 inches, but the differences were not significant. The significant increase in the amount of oxygen that was found in the root zone of the vines grown over tile may have provided an important component in vine survivability. Since soil aeration is important for good root growth, the significant increase in oxygen of tiled soils may have increased root system growth of vines grown over tile. It has been reported that the

Table 2. Influence of soil tiling on soil $\mathrm{pH}$ and relative water content at three depths at Chalet Debonné Vineyards, Madison, Ohio, in Spring 1999.

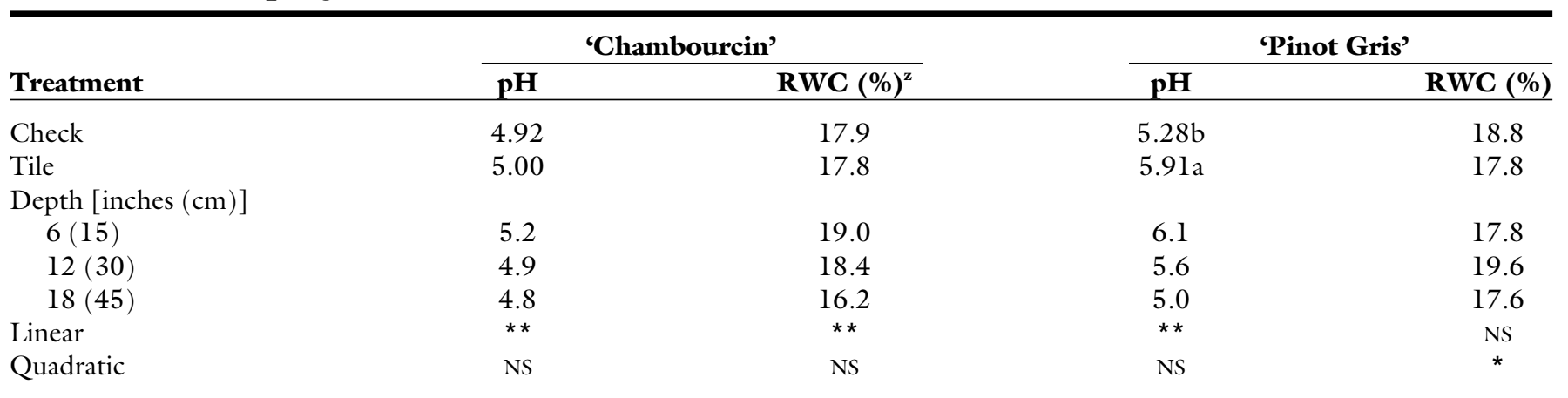

${ }^{\mathrm{z}} \mathrm{RWC}=$ relative water content $=($ wet weight - dry weight $) /$ wet weight

${ }^{* *},{ }^{*}$ Data are significantly different LSD at $P<0.01$ and 0.05 , respectively. 
Table 3. Soil penetrometervalues (lb/inch $\left.{ }^{2}\right)$ in 'Chambourcin' and 'Pinot Gris' vineyards at Chalet Debonné Vineyards, Madison, Ohio, comparing the effect of tiling and location relative to the vine.

\begin{tabular}{|c|c|c|c|c|c|c|c|c|c|}
\hline \multirow[b]{2}{*}{ Treatment } & \multicolumn{8}{|c|}{ Pentrometer values in $1 \mathrm{~b} / \mathrm{inch}^{2}$ at 2 -inch $(5-\mathrm{cm})$ intervals of soil depth } & \multirow{2}{*}{$\begin{array}{c}\text { Avg } \\
\text { compaction }\end{array}$} \\
\hline & 2 & 4 & 6 & 8 & 10 & 12 & 14 & 16 & \\
\hline & \multicolumn{8}{|c|}{ 'Chambourcin' } & \\
\hline \multirow[t]{2}{*}{ Tile } & 245 & 231 & 269 & 256 & 234 & 380 & 517 & 583 & 356 \\
\hline & NS & NS & NS & NS & NS & NS & NS & NS & NS \\
\hline \multicolumn{10}{|l|}{ Location } \\
\hline Aisle & $223 \mathrm{a}$ & $165 \mathrm{~b}$ & $222 b$ & $193 \mathrm{~b}$ & $229 \mathrm{~b}$ & $283 \mathrm{~b}$ & $528 \mathrm{a}$ & $688 \mathrm{a}$ & $313 \mathrm{~b}$ \\
\hline \multicolumn{10}{|c|}{ 'Pinot Gris' } \\
\hline \multicolumn{10}{|l|}{ Treatment } \\
\hline Nontile & 206 & 207 & 217 & 176 & 210 & 306 & 429 & 514 & 283 \\
\hline Tile & 158 & 178 & 188 & 196 & 221 & 271 & 368 & 448 & 283 \\
\hline Aisle & $171 \mathrm{~b}$ & $139 \mathrm{~b}$ & $120 \mathrm{~b}$ & $108 \mathrm{~b}$ & $152 \mathrm{~b}$ & $242 b$ & $502 \mathrm{a}$ & $593 \mathrm{a}$ & $253 \mathrm{~b}$ \\
\hline
\end{tabular}

${ }^{\mathrm{z}}$ Data followed by different letters are significantly different LSD at $P<0.05$

$\mathrm{y} l$ inch $=2.54 \mathrm{~cm} ; 1 \mathrm{lb} / \mathrm{inch}^{2}=6.89 \mathrm{kPa}$.

Table 4. Influence of tile on soil oxygen level under 'Chambourcin' and 'Pinot Gris' cultivars in Spring 1999.

\begin{tabular}{lc}
\hline Treatment & $\begin{array}{c}\text { Diffusion rate } \\
\left(\mu \mathbf{g} \cdot \mathbf{c m}^{\mathbf{z}} \cdot \mathbf{m i n}^{-1}\right)\end{array}$ \\
\hline Check & $0.179 \mathrm{a}$ \\
Tile & $0.226 \mathrm{~b}$ \\
Cultivar & \\
$\quad$ 'Chambourcin' & 0.186 \\
$\quad$ 'Pinot Gris' & 0.218 \\
Depth [inches $(\mathrm{cm})]$ & \\
6 (15) & 0.218 \\
$18(45)$ & 0.186 \\
\hline
\end{tabular}

$\overline{{ }^{z}}$ Data followed by different letters are significantly different LSD at $P<0.05$.

amount of root volume can have an important influence on vine growth and productivity (McArtney and Ferree, 1999b).

\section{Conclusion}

Vines that grew very poorly following the excessively wet year of 1996 recovered by 1999 . The diagonal pattern observed in 1997 was no longer visible in 1999 and vines over tile and between tile lines had similar yields. Prior to our study it was postulated that by digging and refilling the trench to insert the tile, either soil compaction or soil $\mathrm{pH}$ had been altered and could be responsible for the vine performance. Measurements indicated that these factors were not altered enough to explain the growth differences. It does appear that soil oxygen was improved by tiling and this was likely much greater in the excessively wet year resulting in improved vine growth. Although this vineyard is an excellent grape site because of its proximity to Lake Erie with its moderating effect on temperatures, the heavy clay soil caused a problem in vine growth, especially in very wet years. Thus, it appears prudent on soils of this type, tile drainage is beneficial to vines immediately over or adjacent to the lines and spacing of the laterals needs to be closer than $40 \mathrm{ft}$ normally recommended to adequately protect vines in wet years.

\section{Literature cited}

Ferree, D.C., G.A. Cahoon, M.A. Ellis, D.M. Scurlock, and G.R. Johns. 1996. Influence of eight rootstocks on the performance of 'White Riesling' and 'Cabernet Franc' over five years. Fruit Var. J. 50(2):124-130.
Fisher, H.K. 1997. Drainage for optimum vineyard root growth. Wine East. (April)10-20, 41.

McArtney, S.J. and D.C. Ferree. 1999a. Shading effects on dry matter partitioning, remobilization of stored reserves and early season vegetative development of grapevines in the year after treatment. J. Amer. Soc. Hort. Sci. 124(6):591-597.

McArtney, S.J. and D. C. Ferree. 1999b. Root and cane pruning affect vegetative development, fruiting and dry matter accumulation in grapes. HortScience 34(4):617-621.

Nolte, B.H. and N.R. Fausey. 1992. Soil compaction and drainage. Ohio State Univ. Ext. Bul. AEX-301. The Ohio State University, Columbus.

USDA Soil Conservation Service. 1973. Ohio Drainage Guide. Ohio Agr. Res. Dev. Ctr., Ohio State Univ. Ext., Ohio State Univ., Columbus.

USDA Soil Conservation Service. 1973. Soil Survey of Ashtabula County, Ohio. Platea series. Ohio Div. Natural Resources, Ohio Agr. Res. Dev. Ctr., Wooster.

SAS Institute. 1996. SAS 6.12. SAS Institute, Cary, N.C.

Zucker, L.A. and L.C. Brown (eds.). 1998. Agricultural drainage. Ohio State Univ., Columbus, Ext. Bul. 871. 